\title{
Treponema pallidum specific IgM haemagglutination test for serodiagnosis of syphilis
}

\author{
T SATO,* E KUBO,* M YOKOTA,* T KAYASHIMA,* AND T TOMIZAWA† \\ From the *Third Department of the Research Laboratories, Fujirebio Incorporation, and the + Wealmar \\ Research Laboratory, Tokyo, Japan
}

SUMMARY The Treponema pallidum specific IgM haemagglutination (TP-IgM-HA) test uses erythrocytes sensitised with antiserum to human IgM to separate IgM from IgG in serum. Specific antitreponemal IgM captured in this way is detected by adding a second reagent comprising erythrocytes sensitised with $T$ pallidum antigen. Eighty two serum samples from 82 patients with untreated syphilis, 521 samples from 73 patients with treated syphilis, and 1872 samples from people who did not have syphilis were examined by the 19S(IgM)-TPHA ( $T$ pallidum haemagglutination), IgM-FTA-ABS (fluorescent treponemal antibody absorbed), TP-IgM-ELISA (enzyme linked immunosorbent assay), and TP-IgM-HA tests for the presence of 19S(IgM) antibodies specific to treponemes. The sensitivity of the TP-IgM-HA test was $97 \cdot 6 \%$ and the specificity was $99 \cdot 7 \%$.

We also traced IgM specific to treponemes in untreated patients with primary syphilis by four different tests. The TP-IgM-HA test results clearly reflected the effect of the treatment.

\section{Introduction}

The rapid plasma reagin card test (RPR), ${ }^{1}$ the complement fixation test with the cardiolipin antigen (CLCF), ${ }^{2}$ the fluorescent treponemal antibody absorption test (FTA-ABS), ${ }^{3}$ and the Treponema pallidum haemagglutination test (TPHA) ${ }^{4}$ cannot differentiate between patients with active syphilis and those who have been adequately treated. To make a diagnosis of syphilis and to monitor the effect of treatment, several serological tests are performed. These tests are not standardised, however, and their performance is not uniform.

The importance of the treponemal 19S(IgM) diagnostic tests on patients with syphilis has been

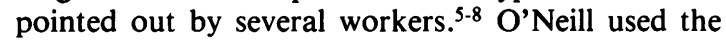
IgM-FTA-ABS test to show treponemal IgM in patients with untreated syphilis, ${ }^{7}$ and Johnston used it on cord and neonatal sera when intrauterine infection of $T$ pallidum was suspected. ${ }^{8}$ This test has not been widely used, however, because of the incidence of false positive and negative reactions and

Address for reprints: Mr Takashi Sato, Third Department of Research Laboratories, Fujirebio Incorporation, 51 Komiya-cho, Hachioji-shi, Tokyo 192, Japan

Accepted for publićation 24 February 1984 technical difficulties. ${ }^{9-12}$ Müller and Oelerich gel filtrated patients serum and fractionated the IgM and IgG. ${ }^{13}$ Examination of these fractions by the TPHA and FTA-ABS tests showed six patterns reflecting stages of syphilis according to the amounts of treponemal IgM and IgG. Schmidt reported the solid phase haemadsorption assay (SPHA) for the rapid detection of treponemal IgM, using the surface of a microplate well. ${ }^{14}$ According to Müller and Lindenschmidt, however, the SPHA, which was associated with a high rate of false negative results in patients with untreated syphilis, did not correlate with the 19S(IgM)-FTA-ABS. ${ }^{15}$ Lindenschmidt and Müller investigated treponemal IgM and IgG by an enżyme linked immunosorbent assay (ELISA) with good results, and concluded that the ELISA should be a reliable tool for mass screening of syphilitic sera. ${ }^{16}$

This paper presents the TP-IgM-HA test, which is easy to perform and does not require special apparatus to detect treponemal IgM. We performed comparative tests for antibodies in $\mathbf{8 2}$ serum samples from 82 patients with untreated syphilis and 521 samples from 73 patients with treated syphilis using the 19S(IgM)-TPHA, 7S(IgG)-TPHA, IgM-FTAABS, IgG-FTA-ABS, TP-IgM-ELISA, TPHA, Venereal Diseases Research Laboratory (VDRL), RPR, CLCF, and TP-IgM-HA tests. 


\section{Material and methods}

\section{SYPHILITIC SERUM SAMPLES}

We tested serum from 37 patients with untreated primary syphilis, 69 patients with secondary syphilis, 29 patients with late syphilis, 14 reinfected patients, and six patients with congenital syphilis. The clinical data were supplied by the Institute of Mandai Clinic in Osaka. An additional 1872 serum samples from patients who attended the same clinic but did not have syphilis were also examined.

\section{FRACTIONATION OF SERUM BY GEL} FILTRATION

A $0.35 \mathrm{ml}$ sample of serum mixed with $0.65 \mathrm{ml}$ of $0.08 \%$ blue dextran 2000 (Pharmacia) was fractionated on a Sephacryl S-300(Pharmacia Fine Chemicals, Sweden) column, $90 \mathrm{~cm} \times 1.6 \mathrm{~cm}$. The blue dextran was eluted in the void volume fractions of the column and almost in the same fractions as the IgM. Elution was performed with $0.5 \mathrm{~mol} / \mathrm{l}$ sodium chloride solution containing $0 \cdot 1 \%$ sodium azide. The flow rate was set at about $12 \mathrm{ml} /$ hour, and every $2.5 \mathrm{ml}$ fraction was collected. Optical absorbance at $280 \mathrm{~nm}$ of eluted fractions showed three peaks corresponding to IgM, IgG, and albumin fractions respectively. The separation of IgM from IgG was confirmed by the IgM-FTA-ABS, IgG-FTA-ABS, and turbidimetric immunoassay (N-TIA) (Nissui Pharmaceutical Co, Tokyo, Japan) tests, which indicated the presence of class specific antibodies only.

TPHA, IgM-FTA-ABS, IgG-FTA-ABS, VDRL, RPR, AND CLCF TEST PROCEDURES

The TPHA, VDRL, and RPR tests were performed according to the instructions of the Japanese manufacturers (Fujirebio, Tokyo, and Kaketsuken, Kumamoto). The FTA-ABS test was performed with $T$ pallidum (Nichols strain) as the antigen, and with sonicated $T$ phagedenis (Reiter strain) as the sorbent.

Antihuman IgM rabbit serum ( $\mu$ chain specific) labelled with fluorescein isothiocyanate (FITC) and antihuman IgG rabbit serum ( $\gamma$ chain specific) were supplied by Dako Immunochemicals (Copenhagen, Denmark). The CLCF test was performed with the cardiolipin antigen (Sumitomo Chemical Co, Tokyo) according to the manufacturer's instructions.

\section{TP-IgM-ELISA PROCEDURE}

Polystyrene beads were coated with $T$ pallidum antigen, washed with phosphate buffered saline (PBS), and stored at $4^{\circ} \mathrm{C}$ in PBS containing $0.1 \%$ bovine serum albumin (BSA) and $0 \cdot 1 \%$ sodium azide for future use. A volume of $400 \mu$ l buffer (containing absorbent) was added to each tube and $5 \mu \mathrm{l}$ of serum specimens and the beads coated with antigen were added. After incubation at $37^{\circ} \mathrm{C}$ for two hours, the beads were washed with saline. A volume of $400 \mu \mathrm{l}$ conjugate (antihuman IgM) was added to each tube and incubated at $37^{\circ} \mathrm{C}$ for one hour. The excess conjugate was removed by washing with saline and $400 \mu \mathrm{l}$ substrate buffer, containing $1 \mathrm{mmol} / \mathrm{l}$ hydrogen peroxide and $0.1 \%$ 2,2'-azino(3-ethylbenzothiazoline-6-sulphonate), was then added and incubated at $37^{\circ} \mathrm{C}$ for one hour. The reaction was stopped by the addition of $2 \mathrm{ml}$ $0.05 \mathrm{~mol} / 1$ oxalic acid, and the aborbance was read at $420 \mathrm{~nm}$. The cut off point between positive and negative was estimated as 1 , which was the quotient of the absorbance at $420 \mathrm{~nm}$ divided by the positive control absorbance.

\section{S(IgM)-TPHA TEST PROCEDURE}

After gel filtration of the serum, 24 fractions were obtained and tested quantitatively using Fujirebio TPHA reagents. The mean of the highest three titres in the IgM and IgG fractions was designated the 19S(IgM)-TPHA titre and 7S(IgG)-TPHA titre respectively.

PREPARATION OF TREPONEMAL ANTIGENS Adult male New Zealand white rabbits were examined on receipt for clinical and serological evidence of $T$ paraluis-cuniculi infection. ${ }^{17}$ The testes of each rabbit were inoculated with $1 \mathrm{ml}$ of $6 \times 10^{7}$ cells $/ \mathrm{ml}$ $T$ pallidum suspension. After 11-13 days the testes were excised from each rabbit and minced. Testicular and red blood cells were removed by differential centrifugation, and the $T$ pallidum organisms extracted were resuspended in PBS to $10 \% / \mathrm{ml}$. The organisms were disrupted by sonication (model UR200P; Tomy Seiko Co, Japan) at $20 \mathrm{kHz}$ for 10 minutes and after the addition of $0.01 \%$ thiomersal (Merthiolate) were stored at $-70^{\circ} \mathrm{C}$ until further use.

\section{PREPARATION OF CELLS SENSITISED WITH ANTIHUMAN-IgM}

Sheep red cells formalinised by the method described by Weinbach ${ }^{18}$ and Wide ${ }^{19}$ were suspended in PBS pH 6.4 at a concentration of $5 \%$ and mixed with an equal volume of 10 parts per million tannic acid solution. The mixture was incubated at $37^{\circ} \mathrm{C}$ for 10 minutes, and the cells washed twice with saline. Equal volumes of the cell suspension and an adequate dilution of the antihuman IgM in PBS pH 6.4 were mixed and incubated for 40 minutes at $37^{\circ} \mathrm{C}$. The sensitised cells were washed twice with saline and resuspended in a suspension medium containing normal rabbit serum (NRS) and stabiliser. The suspended cells were pipetted into each vial, lyophilised, and stored at $4^{\circ} \mathrm{C}$ until used. 
PREPARATION OF CELLS SENSITISED WITH T PALLIDUM

Cells sensitised with $T$ pallidum were prepared similarly to cells sensitised with antihuman IgM. $T$ pallidum disrupted by sonication was adequately diluted and mixed with an equal volume of a suspension of red cells that had been treated with tannic acid. After incubation at $37^{\circ} \mathrm{C}$ for 40 minutes the cells were washed twice with saline. The suspended cells were pipetted into vials, lyophilised, and stored at $4^{\circ} \mathrm{C}$ until used.

\section{TP-IgM-HA PROCEDURE}

A volume of $20 \mu \mathrm{l}$ of serum samples was placed in the far left row of a round bottomed microtitration plate, and $80 \mu \mathrm{l}$ of absorbing diluent containing gum arabic, Tween 80, NRS, and sonicated $T$ phagedenis (Reiter strain) was added to each sample (1/4 dilution). Seventy five $\mu$ l of absorbing diluent was placed into each remaining well.

Lyophilised cells sensitized with antihuman IgM were reconstituted with distilled water, and $25 \mu \mathrm{l}$ of the cell suspension was added to each well and mixed gently by hand or on a tray mixer. The plate was covered with another empty plate and incubated for 15 minutes at $37^{\circ} \mathrm{C}$. The sensitised cells were then washed twice with saline (that is the plate was centrifuged, the supernatant aspirated, and the sensitised cells resuspended in saline). Finally, the cells were suspended in $25 \mu \mathrm{l}$ of absorbing diluent. Lyophilised cells sensitised with $T$ pallidum were reconstituted with distilled water, and $25 \mu \mathrm{l}$ of the cell suspension was added to each well and mixed gently by hand or on a tray mixer. The plate was left overnight without disturbance before reading the results. The patterns were read after two hours or the next day.

\section{Results}

SPECIFICITY OF TP-IgM-HA TEST

Table I shows that of 1712 serum samples from healthy people examined by the TP-IgM-HA method, four gave positive results at a dilution of $1 / 5$, giving a false positive rate of $0 \cdot 23 \%$. Ninety one serum samples from patients with gastric cancer, pancreatic cancer, uterine cancer, and lung cancer were also examined by the TP-IgM-HA tests, and serum from

TABLE I Investigation of the TP-IgM-HA test in nonsyphilitic serum samples

\begin{tabular}{llc}
\hline Serum samples from people with: & $\begin{array}{l}\text { No (\%) false } \\
\text { positives }\end{array}$ & $\begin{array}{l}\text { Speci- } \\
\text { ficity (\%) }\end{array}$ \\
\hline No disease $(\mathrm{n}=1712)$ & $4(0 \cdot 2)$ & $99 \cdot 8$ \\
Cancer $(\mathrm{n}=91)$ & $1(1 \cdot 1)$ & $98 \cdot 9$ \\
Rheumatoid factor $(\mathrm{n}=69)$ & $0(0)$ & 100.0 \\
Total $(\mathrm{n}=1872)$ & $5(0 \cdot 3)$ & 99.7 \\
\hline
\end{tabular}

one patient with gastric cancer gave a positive result. All 69 serum samples from patients with rheumatoid factor gave negative results in the TP-IgM-HA test. Of the 69 patients with rheumatoid factor, nine serum samples from three patients with adequately treated syphilis gave positive results in the IgM-FTAABS test but negative results in the TP-IgM-HA test. In total, five $(0 \cdot 3 \%)$ of the 1872 serum samples gave positive results in the TP-IgM-HA test.

The specificity of the TP-IgM-HA test was confirmed as follows: the serum samples from patients with untreated primary syphilis, which contained both treponemal IgM and IgG, were fractionated on a Sephacryl S-300 column and all 24 fractions were tested by the TPHA and TP-IgM-HA tests. The figure shows that the TPHA test reacted with both IgM and the IgG fractions but the TP-IgM-HA test reacted with IgM fractions only, which suggests that the TP-IgM-HA test detects only treponemal IgM.

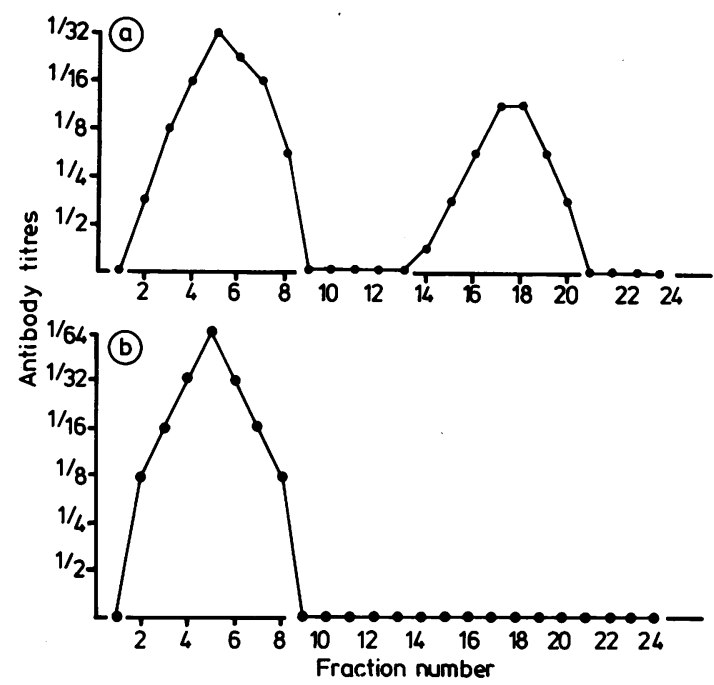

FIGURE Distribution of immunogioblins in serum of untreated patients with primary syphilis after gel filtration in (a) the TPHA test and (b) the TP-IgM-HA test.

SENSITIVITY OF TP-IgM-HA TEST

Table II shows the results of the TP-IgM-HA test on 82 serum samples giving positive results to the 19S(IgM)-TPHA test from patients with untreated primary and secondary syphilis. With one exception, 37 serum samples from patients with untreated primary syphilis that gave positive results to the 19S(IgM)-TPHA test also gave positive results to the TP-IgM-HA test. The one exception gave weakly positive results in the 19S(IgM)-TPHA test and borderline results in the IgM-FTA-ABS test, but gave negative results to the RPR and CLCF tests. With 
TABLE II Sensitivity of the TP-IgM-HA test in serum samples from patients with untreated primary and secondary syphilis reactive in the $19 S(\operatorname{IgM})$-TPHA test

\begin{tabular}{|c|c|c|c|c|c|c|c|}
\hline \multirow{3}{*}{$\begin{array}{l}\text { Serum samples } \\
\text { positive to } 19 S \\
\text { (IgM)-TPHA } \\
\text { test from un- } \\
\text { treated patients } \\
\text { with: }\end{array}$} & \multicolumn{6}{|c|}{ Results of TP-IgM-HA tests } & \multirow{3}{*}{$\begin{array}{l}\text { Sens } \\
\text { tivity } \\
\text { (\%) }\end{array}$} \\
\hline & \multicolumn{5}{|c|}{ No positive at titres of: } & \multirow{2}{*}{$\begin{array}{l}\text { No (\%) } \\
\text { negative }\end{array}$} & \\
\hline & $1 / 5$ & $1 / 20$ & $1 / 80$ & $1 / 320$ & $1 / 1280$ & & \\
\hline \multirow{2}{*}{$\begin{array}{c}\text { Primary } \\
(n=37) \\
\text { Secondary } \\
(n=45)\end{array}$} & 10 & 12 & 9 & 4 & 1 & $1(2 \cdot 7)$ & $97 \cdot 3$ \\
\hline & 16 & 19 & 5 & 3 & 1 & $1(2 \cdot 2)$ & $97 \cdot 8$ \\
\hline Total $(n=82)$ & 26 & 31 & 14 & 7 & 2 & $2(2 \cdot 4)$ & $97 \cdot 6$ \\
\hline
\end{tabular}

one exception, 45 serum samples from patients with untreated secondary syphilis that gave positive results to the 19S(IgM)-TPHA test also gave positive results to the TP-IgM-HA test. The one exception gave negative results to the IgM-FTA-ABS and TP-IgMELISA tests.

Overall, the sensitivity of the TP-IgM-HA test in untreated primary and secondary syphilis was $\mathbf{9 7 \cdot 6 \%}$.

COMPARISON OF ANTIBODY TITRES AND

UNITS IN DIFFERENT TESTS

Table III compares antibody titres estimated by the
19S(IgM)-TPHA and TP-IgM-HA tests. As we expected, the results correlated well. Table IV compares antibody titres estimated by the IgM-FTAABS and TP-IgM-HA tests. They also correlated well. Nine serum samples from patients with rheumatoid factor and five from patients who had been reinfected with $T$ pallidum showed irregular results. Table $\mathrm{V}$ compares antibody units and titres estimated by the TP-IgM-ELISA and TP-IgM-HA tests. Eight serum samples from patients reinfected with $T$ pallidum showed irregular results.

\section{CHANGES IN TP-IgM-HA TITRES AFTER TREATMENT}

One of the 108 serum samples from patients with adequately treated syphilis gave positive results to the TP-IgM-HA test and also in the 19S(IgM)-TPHA test.

Table VI shows the changes in the antibody titres and units to the nine tests before and after treatment with penicillin in two patients with primary syphilis. In the VDRL, CLCF, 19S(IgM)-TPHA, TP-IgMELISA, and TP-IgM-HA tests the antibody titre or unit decreased rapidly after treatment. In the TPIgM-HA and IgM-FTA-ABS tests the titre changed to negative or boderline within four to five months.

TABLE III Comparison of antibody titres in the TP-IgM-HA and 19S(IgM)-TPHA tests

\begin{tabular}{|c|c|c|c|c|c|c|c|}
\hline \multirow[b]{3}{*}{$19 S(\operatorname{IgM})-T P H A$ test } & \multicolumn{6}{|c|}{$T P-I g M-H A$ test-No of serum samples giving: } & \multirow[b]{3}{*}{ Total } \\
\hline & \multirow{2}{*}{$\begin{array}{l}\text { Negative } \\
\text { results }\end{array}$} & \multicolumn{4}{|c|}{ Positive results at titres of: } & \multirow[b]{2}{*}{$I / 1280$} & \\
\hline & & $1 / 5$ & $1 / 20$ & $1 / 80$ & $1 / 320$ & & \\
\hline \multicolumn{8}{|l|}{ No of serum samples giving: } \\
\hline Negative results (titres of $0-1 / 1 \cdot 9$ ) & 157 & 10 & 5 & & & & 172 \\
\hline \multicolumn{8}{|l|}{ Positive results at titres of: } \\
\hline $1 / 2-1 / 3 \cdot 9$ & 15 & 159 & 10 & 1 & & & 185 \\
\hline $1 / 4-1 / 7 \cdot 9$ & 10 & 17 & 97 & 5 & & & 129 \\
\hline $1 / 8-1 / 15 \cdot 9$ & & 6 & 10 & 22 & 1 & & 39 \\
\hline $1 / 16-1 / 31 \cdot 9$ & & & 2 & 2 & 12 & & 16 \\
\hline over $1 / 32$ & & & & & 1 & 1 & 2 \\
\hline Total & 182 & 192 & 124 & 30 & 14 & 1 & 543 \\
\hline
\end{tabular}

TABLE IV Comparison of antibody titres in the TP-IgM-HA and IgM-FTA-ABS tests

\begin{tabular}{|c|c|c|c|c|c|c|c|}
\hline \multirow{2}{*}{ IgM-FTA-ABS test } & \multicolumn{6}{|c|}{ TP-IgM-HA test-No of serum samples giving: } & \multirow{2}{*}{ Total } \\
\hline & $\begin{array}{l}\text { Negative } \\
\text { results }\end{array}$ & \multicolumn{5}{|c|}{ Positive results at titres of: } & \\
\hline \multicolumn{8}{|l|}{ No of serum samples giving: } \\
\hline Negative results & 134 & 17 & $5^{*}$ & & & & 156 \\
\hline \multicolumn{5}{|l|}{ Positive results at titres of: } & & & 139 \\
\hline $1 / 20$ & $9+$ & 10 & 98 & 11 & 6 & & 134 \\
\hline $1 / 80$ & & 1 & 4 & 15 & 6 & & 26 \\
\hline $1 / 320$ & & & & 1 & 3 & & 4 \\
\hline $1 / 1280$ & & & & & & 1 & 1 \\
\hline Total & 158 & 138 & 119 & 29 & 15 & 1 & 460 \\
\hline
\end{tabular}

* Patients with reinfection.

+ Patients with rheumatoid factor. 
TABLE V Comparison of TP-IgM-HA antibody titres and TP-IgM-ELISA antibody units

\begin{tabular}{|c|c|c|c|c|c|c|c|}
\hline \multirow[b]{3}{*}{$T P-I g M-E L I S A$} & \multicolumn{6}{|c|}{ TP-IgM-HA test-No of serum samples giving: } & \multirow[b]{3}{*}{ Total } \\
\hline & \multirow{2}{*}{$\begin{array}{l}\text { Negative } \\
\text { results }\end{array}$} & \multicolumn{5}{|c|}{ Positive results at titres of: } & \\
\hline & & $1 / 5$ & $I / 20$ & $1 / 80$ & $1 / 320$ & $1 / 1280$ & \\
\hline $\begin{array}{l}\text { No of serum samples giving: } \\
\text { Negative results (units of } 0-0.9 \text { ) } \\
\text { Positive results at units of: }\end{array}$ & 44 & 8 & $5^{*}$ & $3^{*}$ & & & 60 \\
\hline $\begin{array}{l}1-1 \cdot 9 \\
2-2 \cdot 9 \\
3-3 \cdot 9 \\
\text { over } 4\end{array}$ & $\begin{array}{r}11 \\
2\end{array}$ & $\begin{array}{r}45 \\
8 \\
6\end{array}$ & $\begin{array}{r}5 \\
10 \\
3 \\
1\end{array}$ & $\begin{array}{l}2 \\
2 \\
7\end{array}$ & $\begin{array}{l}1 \\
2 \\
5 \\
1\end{array}$ & & $\begin{array}{r}64 \\
24 \\
21 \\
2\end{array}$ \\
\hline Total & 57 & 67 & 24 & 14 & 9 & & 171 \\
\hline
\end{tabular}

*Patients with reinfection.

On the other hand, in the 19S(IgM)-TPHA test a treponemal IgM of around 2 units was seen even five months after treatment.

\section{Discussion}

At present the IgM-FTA-ABS test is the most widely used method to identify $T$ pallidum specific IgM antibodies. This method, however, produces incorrect results due to various factors in the serum such as excess quantities of $T$ pallidum specific $\mathrm{IgG}$, rheumatoid factor, $T$ pallidum specific $8 \mathrm{~S}$ IgM, and IgM-anti-IgG autoantibodies. ${ }^{20}$ Further cumbersome test procedures make mass assays troublesome and laborious.

While Schmidt used the wall of the microplate well, ${ }^{14}$ we used the surface of fixed sheep erythrocytes sensitised with antiserum to human IgM to extract IgM from the serum. A bonding between polystyrene, a material of the microplate, and the erythrocytes sensitised with rabbit antiserum to human IgM is the result of hydrophobic adherence. Thus, the erythrocytes sensitised with rabbit antiserum to human IgM are easily dissociated by washing or combination with the erythrocytes sensitised with purified $T$ pallidum. For this reason considerable variations in the titre depend on the method of washing and on the concentration of the erythrocytes sensitised with purified $T$ pallidum. In contrast, when the erythrocytes are sensitised with rabbit antiserum to human IgM with tannic acid, it becomes a strong bonding agent mediated by a covalent bond. Accordingly, in the TP-IgM-HA test the frequency of washing or the concentration of the erythrocytes sensitised with purified $T$ pallidum is of little importance. Moreover, when fewer than 24 samples are tested all the test procedures are completed within two hours, and results are available two hours later.

TABLE VI Comparison of the TP-IgM-HA titres with other serological test titres and units after treatment of patients with primary syphilis

\begin{tabular}{|c|c|c|c|c|c|c|c|c|c|}
\hline \multirow[b]{2}{*}{$\begin{array}{l}\text { Time after } \\
\text { treatment }\end{array}$} & \multicolumn{9}{|c|}{ Titres and units at which positive results were given by the following tests: } \\
\hline & $V D R L$ & $C L C F$ & $T P H A$ & $\begin{array}{l}\text { I9S(IgM) } \\
-T P H A\end{array}$ & $\begin{array}{l}7 S(1 g G) \\
-T P H A\end{array}$ & $\begin{array}{l}I g M-F T A \\
-A B S\end{array}$ & $\begin{array}{l}I g G-F T A \\
-A B S\end{array}$ & $\begin{array}{l}T P-I g M \\
-E L I S A\end{array}$ & $\begin{array}{l}T P \cdot I g M \\
-H A\end{array}$ \\
\hline $\begin{array}{l}\text { Case I (female, } \\
0 \\
5 \text { days } \\
19 \text { days } \\
1 \text { month } \\
2 \text { months } \\
4 \text { months } \\
5 \text { months }\end{array}$ & $\begin{array}{c}1 / 32 \\
1 / 64 \\
1 / 32 \\
1 / 8 \\
1 / 4 \\
1 / 2 \\
*\end{array}$ & $\begin{array}{r}1 / 320 \\
1 / 640 \\
1 / 160 \\
1 / 80 \\
1 / 160 \\
1 / 10 \\
*\end{array}$ & $\begin{array}{l}1 / 80 \\
1 / 80 \\
1 / 80 \\
1 / 80 \\
1 / 320 \\
1 / 320 \\
1 / 320\end{array}$ & $\begin{array}{r}1 / 10 \cdot 2 \\
1 / 16 \cdot 0 \\
1 / 16 \cdot 0 \\
1 / 8 \cdot 3 \\
1 / 4 \cdot 0 \\
1 / 3 \cdot 3 \\
1 / 2 \cdot 1\end{array}$ & $\begin{array}{r}* \\
* \\
* \\
* \\
1 / 2 \cdot 8 \\
1 / 5 \cdot 9 \\
1 / 5 \cdot 2\end{array}$ & $\begin{array}{l}1 / 80 \\
1 / 20 \\
1 / 20 \\
1 / 20 \\
1 / 20 \\
1 / 20 \\
1 / 5\end{array}$ & $\begin{array}{r}* \\
1 / 5 \\
1 / 20 \\
1 / 20 \\
1 / 80 \\
1 / 80 \\
1 / 80\end{array}$ & $\begin{array}{l}3 \cdot 2 \\
3 \cdot 3 \\
2 \cdot 9 \\
2 \cdot 3 \\
1 \cdot 7 \\
1 \cdot 6 \\
(0 \cdot 9) *\end{array}$ & $\begin{array}{r}1 / 320 \\
1 / 320 \\
1 / 320 \\
1 / 80 \\
1 / 20 \\
1 / 5 \\
*\end{array}$ \\
\hline $\begin{array}{l}\text { Case } 2 \text { (male) } \\
0 \\
2 \text { weeks } \\
1 \text { month } \\
2 \text { months } \\
3 \text { months } \\
4 \text { months } \\
5 \text { months }\end{array}$ & $\begin{array}{c}1 / 16 \\
1 / 32 \\
1 / 8 \\
1 / 4 \\
1 / 2 \\
1 / 1 \\
\end{array}$ & $\begin{array}{r}1 / 640 \\
1 / 640 \\
1 / 640 \\
1 / 160 \\
1 / 80 \\
1 / 20\end{array}$ & $\begin{array}{r}1 / 160 \\
1 / 80 \\
1 / 80 \\
1 / 80 \\
1 / 80 \\
1 / 80 \\
1 / 80\end{array}$ & $\begin{array}{r}1 / 32 \cdot 3 \\
1 / 25 \cdot 7 \\
1 / 16 \cdot 6 \\
1 / 3 \cdot 6 \\
1 / 3 \cdot 6 \\
1 / 4 \cdot 0 \\
1 / 2 \cdot 0\end{array}$ & $\begin{array}{r}* \\
* \\
1 / 0 \cdot 5 \\
1 / 3 \cdot 3 \\
1 / 4 \cdot 0 \\
1 / 5 \cdot 1\end{array}$ & $\begin{array}{r}* \\
1 / 5 \\
1 / 5 \\
1 / 20 \\
1 / 20 \\
1 / 5 \\
*\end{array}$ & $\begin{array}{r}1 / 320 \\
1 / 320 \\
1 / 80 \\
1 / 80 \\
1 / 80 \\
1 / 20 \\
1 / 20\end{array}$ & $\begin{array}{l}4.4 \\
4.0 \\
3.5 \\
2.4 \\
1.5 \\
(0.8)^{*} \\
(0.6)^{*}\end{array}$ & $\begin{array}{r}1 / 1280 \\
1 / 320 \\
1 / 320 \\
1 / 80 \\
1 / 5 \\
* \\
*\end{array}$ \\
\hline
\end{tabular}

VDRL = Venereal Diseases Research Laboratory test; $C L C F=$ complement fixation with cardiolipin antigen test; TPHA $=$ Treponema pallidum haemagglutination assay; FTA-ABS = fluorescent treponemal antibody absorption test; ELISA = enzyme linked immunosorbent assay. ${ }^{*}=$ negative reaction. 
The specificity of the TP-IgM-HA test was $99 \cdot 7 \%$. All serum containing rheumatoid factor gave negative results to the test. The five false positive serum samples were gel filtrated on a Sephacryl S-300 column and separated into IgM and IgG fractions. The IgM fractions gave positive results but the IgG fractions negative results to the TP-IgM-HA test. It was recognised that the false positive non-specific factor was associated with the 19S(IgM) class. The sensitivity of the TP-IgM-HA test serum samples from patients with untreated primary and secondary syphilis was $97 \cdot 3 \%$ and $97.8 \%$ respectively. Overall, the sensitivity of the TP-IgM-HA test in untreated primary and secondary syphilis was $97 \cdot 6 \%$. Unfortunately we could not obtain serum samples from patients with untreated late latent syphilis. The antibody titre results of the 19S(IgM)-TPHA and the TPIgM-HA tests showed a good correlation (table III). Twenty five of the serum samples giving positive results to the 19S(IgM)-TPHA and the TP-IgM-HA tests gave negative reactions to the IgM-FTA-ABS test. Of the nine 19S(IgM)-TPHA positive serum samples from patients who had been reinfected with syphilis, one gave negative reactions to the TP-IgMHA and the IgM-FTA-ABS tests and the other eight gave positive reactions to the TP-IgM-HA test.

The antibody titres estimated by the TP-IgM-HA and the IgM-FTA-ABS tests also correlated well (table IV). All nine serum samples that gave positive results to the IgM-FTA-ABS test and negative results to the TP-IgM-HA test contained rheumatoid factor. We assumed these serum samples gave false positive reactions to the IgM-FTA-ABS test due to the presence of rheumatoid factor. All five serum samples that gave negative results to the IgM-FTAABS test and positive results to the TP-IgM-HA test (at a serum dilution of $1 / 20$ ) were from reinfected patients. All of these reinfected serum samples showed high titres to the TPHA and FTA-ABS tests. Presumably a false negative result may occur by competitive inhibition between excess treponemal IgG and deficient treponemal IgM on the surface of $T$ pallidum.

The TP-IgM-HA and TP-IgM-ELISA tests (table V) also correlated well. Eight sera from reinfected patients gave positive results to the TP-IgM-HA test but negative results to the TP-IgM-ELISA test. Five serum samples from reinfected patients gave negative results to the IgM-FTA-ABS test. The TP-IgM-ELISA and IgM-FTA-ABS tests are based on similar techniques-that is, all classes of treponemal antibodies in the specimen may be associated with the T pallidum antigen, and the treponemal IgM is detected by the labelled antihuman IgM. Excess treponemal IgG, however, disturbs the attachment of the treponemal IgM to the surface of the $T$ pallidum antigen. As a result, a false negative result occasionally occurs in reinfected patients.

One of the 108 serum samples from adequately treated patients gave positive results to the TP-IgMHA test; treponemal IgM was also detected in the 19S(IgM)-TPHA, IgM-FTA-ABS, TP-IgM-ELISA tests in the case of treated serum samples. We therefore assumed that treponemal IgM continues to exist in the patient for some reason despite adequate treatment. A 62 year old man had been treated inadequately with arsphenamine (salvarsan). Twenty years later he was given penicillin treatment, but the treponemal IgM did not decrease. Further investigations and discussions are necessary to ascertain the reason for this.

We believe that the TP-IgM-HA test, which can easily detect treponemal IgM in a short time and has high specificity and high sensitivity in detecting treponemal IgM, will be a most effective tool in obtaining information on the necessity and monitoring of treatment of syphilis.

We thank Professor $Z$ Yoshii of Ube University, the late Dr Y Nakamizo, and Dr M Fukuyama for their valuable guidance. We also thank $\mathrm{Dr} \mathrm{H}$ Tsugami and $\mathrm{K}$ Matsunaga of the Institute of Mandai Clinic, Osaka, for providing specimens and valuable data.

\section{References}

1. Portnoy J, Brewer JH, Harris A. Rapid plasma reagin card test for syphilis and other treponematoses. Public Health Rep 1962; 77:645-52.

2. Yamamoto K, Murata R. Manual for serodiagnosis of syphilis. Tokyo: Association of Public Health in Japan, 1969:1-73.

3. Hunter EF, Deacon WE, Mayer PE. An improved FTA test of syphilis, the absorption procedure (FTA-ABS). Public Health Rep 1964; 79:410-2.

4. Tomizawa T, Kasamatsu S, Yamaya S. Usefulness of the haemagglutination test using Treponema pallidum antigen (TPHA) for the serodiagnosis of syphilis. Jpn J Med Sci Biol 1969; 22:341-50.

5. Atwood WG, Miller JL. Fluorescent treponemal antibodies in fractionated syphilitic sera. The immunoglobulin class. Arch Dermatol 1969;100:763-9.

6. Julian AJ, Logan LC, Norins LC. Early syphilis: immunoglobulins reactive in immunofluorescence and serological tests. J Immunol 1969; 102: 1250-9.

7. O'Neill P, Nicol CS. IgM class antitreponemal antibody in treated and untreated syphilis. Br J Vener Dis 1972; 48:460-3.

8. Johnston NA. Neonatal congenital syphilis. Diagnosis by the absorbed fluorescent treponemal antibody (Ig) test. $\mathrm{Br} J$ Vener Dis 1972; 48:464-9.

9. Múller F, Loa PL. New possibilities in the immunological diagnosis of treponemal infection (syphilis). Infection 1974; 2:127-31.

10. Muller $\dot{F}$, Oelerich $\mathbf{S}$. Correlation between immunological parameters and the stage of clinical or latent syphilis. Dermatol Monatsschr 1979; 165:385-95.

11. Cohen IR, Norins LC, Jilian AJ. Competition between and effectiveness of IgG and IgM antibodies in indirect antibody and other tests. J Immunol 1967;98:143-9.

12. Muller F. Zur Technik des Nachweises treponemenspezifischer 19S-IgM-Antikororper bei der latenten und spătlatenten Syphilis. Immun Infekt 1977; 5:109-13.

13. Muller F, Oelerich S. Serological patterns and their correlation with clinically apparent or latent syphilis. WHO/VDT/RES, 1979; 79:361. 
14. Schmidt BL. Solid-phase hemadsorption: a method for rapid detection of Treponema pallidum-specific IgM. Sex Transm Dis 1980; 7:53-8.

15. Müler $\mathbf{F}$, Lindenschmidt E-G. Demonstration of specific 19S(IgM) antibodies in untreated and treated syphilis. $\mathrm{Br} J$ Kener Dis 1982;58:12-7.

16. Lindenschmidt E-G, Müller F. A treponema-specific soluble antigen for an IgM- and IgG-TP-ABS-ELISA and its application for the serodiagnosis of syphilis. WHO/VDT/RES 1981; 81:369.

17. Lukehart SA, Baker-Zander SA, Sell S. Characterization of lymphocyte responsiveness in early experimental syphilis. I. In vitro response to mitogens and Treponema pallidum antigens. $J$ Immunol 1980; 124:454.
18. Weinbach $R$, Die Verwendbarkeit formolbehandelter Erythrozyten als Antigenträger in der indirekten Haemagglutination. II. Schweizerische Zeitschrift für Allgemeine Pathologie und Bakteirologie 1959;22:1-11.

19. Wide L. An immunological method for the assay of human chorionic gonadotropin. Acta Endocrinol 1962;70suppl.

20. Muller F, Oelerich S. Identification of a low molecular weight IgM antibody with Treponema pallidum specificity in sera of patients with chronic syphilis. Klin Wochenschr 1979; 67.667.71 